\title{
The Effectiveness of the Application of the Cheerful and Creative Children's Gymnastics Model to Improve the Physical Fitness of Kindergarten Children
}

\author{
Noviria Sukmawati ${ }^{1,}$, Firmansyah Dlis ${ }^{1}$, Ramdan Pelana $^{1}$, Muslimin $^{2}$, Oktariyana $^{3}$ \\ ${ }^{1}$ Department of Physical Education, Postgraduate Program, Jakarta State University, Jakarta, Indonesia \\ ${ }^{2}$ Department of Sport Education, Bina Darma University, Palembang, Indonesia \\ ${ }^{3}$ Department of Physical Education, University PGRI Palembang, South Sumatera, Indonesia
}

Received May 26, 2021; Revised August 13, 2021; Accepted September 19, 2021

\section{Cite This Paper in the following Citation Styles}

(a): [1] Noviria Sukmawati, Firmansyah Dlis, Ramdan Pelana, Muslimin, Oktariyana, "The Effectiveness of the Application of the Cheerful and Creative Children's Gymnastics Model to Improve the Physical Fitness of Kindergarten Children," International Journal of Human Movement and Sports Sciences, Vol. 9, No. 6, pp. 1109 - 1117, 2021. DOI: 10.13189/saj.2021.090605.

(b): Noviria Sukmawati, Firmansyah Dlis, Ramdan Pelana, Muslimin, Oktariyana (2021). The Effectiveness of the Application of the Cheerful and Creative Children's Gymnastics Model to Improve the Physical Fitness of Kindergarten Children. International Journal of Human Movement and Sports Sciences, 9(6), 1109 - 1117. DOI: 10.13189/saj.2021.090605.

Copyright $\odot 2021$ by authors, all rights reserved. Authors agree that this article remains permanently open access under the terms of the Creative Commons Attribution License 4.0 International License

\begin{abstract}
The purpose of this study was to determine the effectiveness of the application of the Cheerful and Creative Child Gymnastics model to improve the physical fitness of kindergarten children. This study uses a quantitative approach. The design used in this study was a pretest-posttest control group design. This study uses a physical fitness instrument designed specifically for children aged 3 and 7 years, namely the PREFIT Battery Test. From the results of PREFIT battery test data for kindergarten children with the test subjects totaling 60 kindergarten children (experimental group $(n=30)$ and control group $(\mathrm{n}=30)$, it is known that the significance value (sig.) is the Kolmogorov-Smirnov test and the Shapiro-test. Wilk > 0.05 then the data is normally distributed. Based on the results of the t-test using the independent sample test, the value of Sig (2-tailed) is 0.028 $<0.05$, therefore Ho (Statistical Hypothesis) is rejected and Ha (Alternative Hypothesis) is accepted so that there is an average difference. The mean significant difference exists between the post-test results of the experimental group and the post-test of the control group. To determine the effectiveness of the application of the Cheerful and Creative Children's exercise model, it can be tested by calculating the N-Gain Score, the average value of the
\end{abstract}

$\mathrm{N}$-gain score for the experimental class is $77.51 \%$ in the "Effective" category, with a minimum $\mathrm{N}$-gain score of $48.30 \%$ and a maximum $\mathrm{N}$-gain score of $100 \%$, while the average $\mathrm{N}$-gain score for the control class is $52.93 \%$ in the "Less Effective" category with a minimum $\mathrm{N}$-gain score of $22.20 \%$ and a maximum $\mathrm{N}$-gain score of $100 \%$. Thus, the application of the "Effective" Cheerful and Creative Child Gymnastics model can improve the physical fitness of kindergarten children.

Keywords Gymnastics, Physical Fitness, Kindergarten Children

\section{Introduction}

Early childhood education seeks to develop physical, cognitive, artistic, language, emotional, social, and moral aspects, and religion of children from birth to six years of age through the provision of education to have the readiness to learn at the next level of education. According to Rahman [1] early childhood is a child who has an age between 0 and years". In general, the purpose 
of early childhood education is to develop various potentials of children from an early age as preparation for life and being able to adapt to their environment. The purpose of establishing early childhood education is to train children's cognitive, affective, and psychomotor from an early age using the play method. Aspects that are integrated into playing are psychomotor supported by other aspects. Psychomotor have a close relationship with the movement and physical fitness of children [2]. It is important to give to the nation's children early childhood education because early childhood ( $0-8$ years) is a golden age in the process of brain growth and development so it is very appropriate to foster and develop all the potential of children, for example, intellectual, emotional, personality, and physical. Regarding the importance of physical activity for early childhood Overy \& Szakacs [3] explains that Physical activity can improve the development of brain function, coordination, social skills, gross motor skills, emotions, leadership, and imagination. It can be concluded that the purpose of physical activity is to make as much control of physical activity as possible connected to the brain so that the brain can control various kinds of movements when doing physical activity or sports in the future.

Early childhood can memorize rote, of course with good stimulation will be beneficial for children. Kadir [4] argues that "physical activity, motion, and song can make a big contribution to balancing the brain of early childhood, by combining physical activity (sports) and listening to music or singing, can help brain development".

Based on observations, it was found that there were several early childhood education teachers in Belitang District, and three were several problems related to physical fitness for early childhood, namely the lack of motor learning in early childhood education by teachers aimed at improving physical fitness and having never done fitness test activities. Physical education in kindergarten children in Belitang OKU Timur District, it is important to know the level of physical fitness in children which is expected to be a reference material for educators as a benchmark in achieving learning objectives, especially in children's physical motoric material.

The material presented in kindergarten education, especially those im to improve physical fitness, can include movement and songs, namely gymnastics. Movement activities and songs for early childhood can help stimulate both hemispheres of the child's brain [5]. Because motion and song are some of the most fun activities for early childhood. In addition to having benefits in children's brain development, movement and song activities make a big contribution to early childhood brain development. Music or songs have positive values that help children's development from an early age. It cah in crease children's brain abilities, improve memory, help children socialize, increase self-confidence andpatience, help children contact with others, learn discipline, and develop creativity.

Through the movements and songs given in improving the physical fitness of early childhood, one of them is the application of the Cheerful and Creative Children's Gymnastics model. Cheerful and Creative Children's Gymnastics is a series of gymnastic movements that combines several basic movements of rhythmic gymnastics by combining several activity themes that are adapted to the development and characteristics of children aged 5-6 years, namely the theme of myself (warming movement), transportation theme (core movement 1 ), the theme of the profession (core movement 2), animal theme (core movement 3) and the theme of the surrounding nature (cooling movement) to generate creativity and expression movement so that the expected goals are achieved so that by doing the Cheerful and Creative Children's gymnastics activities can improve childs fitness. One way to grow children's creativity and potential is to provide children with artistic experiences. The art experience can be in the form of dancing (dance), playing music (music), and playing drama (performing art) [6]. The experience will stimulate the child's senses, so that the child becomes expressive, creative, and imaginative.

\section{Material and Methods}

\subsection{Gymnastics}

Gymnastics is a body exercise that is created intentionally, systematically arranged and carried out consciously to form and develop a person in harmony. Gymnastics is an optimization of children's developmental physical activity [7]. The development of children that can be formed is endurance, agility, intelligence, flexibility, and good body coordination. Meanwhile, according to another definition, Caine [8] "Gymnastics is a sport characterized by early intensive practice. It can represent the most demanding sport in which performance excellence is reached during childhood and early adolescence. Childhood and adolescence are periods of enormous skeletal growth (at the end of adolescence, the major part of adult bone mass is acquired".

Meanwhile, another opinion states that, Gymnastics' subgroups are composed of a series of moves that include several movements in the form of simple, complex, static and dynamic techniques that are marked with a precise definition [9]. According to Fahrezi [10] who stated that: "Gymnastics are physical exercises that are selected, arranged and arranged systematically so that they are useful for increasing and improving flexibility, attitude, health, and physical fitness".

There are various types of gymnastics, one of which is rhythmic gymnastics. Rhythmic Gymnastics is also known as rhythmic gymnastics. "Rhythmic gymnastics is 
defined as a high leap demanding sport. Leaping ability is a basic component of rhythmic gymnastics, expected to execute both leap difficulties and choreographic elements" [11]. Rhythmic gymnastics movements follow the rhythm used and prioritize elements of beauty, subtlety, flexibility, harmony of motion, and accuracy of motion to the rhythm of the accompaniment.

Rhythmic gymnastics movements follow the rhythm used and prioritize elements of beauty, subtlety, flexibility, harmony of motion, and accuracy of motion to the rhythm of the accompaniment. The classification of gymnastics is rhythmic or rhythmic gymnastics. Rhythmic gymnastics is a gymnastic movement that combines various forms of movement with the rhythm that accompanies it, for example combining the rhythm of clapping, tapping, tambourine, singing, music and so on. Sutisna [12] explains that "rhythmic gymnastics is gymnastics that is accompanied by rhythm and the movements must follow the rhythm". Rhythmic gymnastics is a sport that can be done individually or in groups. Rhythmic gymnastics is very good for body fitness and the formation of body parts. Good and appropriate movements in rhythmic gymnastics activities will produce maximum results as expected. Another definition according to Caine et al., [13] explains that "Gymnastics is a sport characterized by early intensive practice. It can represent the most demanding sport in which performance excellence is reached during childhood and early adolescence. Childhood and adolescence are periods of enormous skeletal growth (at the end of adolescence, the major part of adult bone mass is acquired)".

Rhythmic gymnastics can be done with or without equipment. The movements can be varied in such a way to suit the accompaniment of music, singing, or counting. This is in line with the opinion of Mehrtash et al., [14] who argues that "training or learning rhythmic activities can improve students' motor skills". It can be concluded that the development of learning materials with rhythmic gymnastics can improve the cognitive, effective and psychomotor development of students through learning adapted to the ability and type of music according to the child's character. With good motor skills, gymnastics can also improve fitness in children.

From some of the definitions of rhythmic gymnastics above, it can be concluded that rhythmic gymnastics is gymnastics that is carried out to channel a sense of the art of movement. In principle, rhythmic gymnastics aims to make the body fit, flexible, and make the heart happy. The freedom of body movement gained through dance will result in balance, timing, strength, and coordination. Or it can also be interpreted rhythmic gymnastics is gymnastics whose movements are rhythmic, accompany it with a combination of various rhythmic movements, accompaniment can be in the form of clapping, tapping, singing, music, and so on. Rhythmic gymnastics can be done without tools or can be done with tools.

\subsection{Physical Fitness}

Physical fitness focuses more on physiological fitness, namely the ability of bady to adjust the functions of its organs within physiological limits to environmental conditions and or physical work in a fairly efficient manner without being excessively tired [15]. Physical fitness is the capacity to perform physical activity, which refers to a full range of physiological and psychological qualities [16]. Physical fitness is related to a person's activities / activities in carrying out activities and moving. Physical fitness is needed to support a person's daily activities so that these activities are optimal. According to Sukadiyanto [17] explains "in general what is meant by physical fitness is physical fitness, namely the ability of a person to do daily work efficiently without excessive fatigue so that they can still enjoy their free time.

Physical fitness includes a state of physical health and the ability to work efficiently without causing significant fatigue. Thus, physical fitness is the main capital in carrying out daily work as needed. This means that physical fitness is a reflection of the ability of system functions in the body that can improve the quality of life in every physical activity. Physical fitness is the condition of a person's body, which has an important role in daily activities or activities. Every individual needs to have an ideal level of physical fitness. It is adapted to the demands of tasks and activities in daily life. Nurhasan [18] explains that "Physical fitness is the ability of a person's body to perform daily work tasks, without causing significant fatigue." As for the opinion of Pinho et al., [19] "Practicing physical activities has a key role in the levels of physical fitness and is essential to balance and improve health and quality of life during the COVID-19 pandemic because it reduces the levels of physical inactivity and sedentary behavior". The importance of physical fitness activities for the body is to improve one's health and quality of life. So it can be concluded that physical fitness is a person's ability to perform daily work efficiently without causing significant fatigue, so that they still have sufficient energy reserves to carry out further activities.

\subsection{Early Childhood Education}

Early childhood education in general is a coaching effort carried out through providing educational stimuli for children aged from birth to six years of age. According to the opinion Sasongko [20], "early childhood education is essentially an education organized to facilitate the growth of the child as a whole or emphasize the development of all aspects of the child's personality. Every early childhood development has certain characteristics or developmental tasks that can be used as standards/estimates about things that must be mastered by children at a certain stage.

Early childhood education is a coaching effort aimed at children from birth to the age of six which is carried out 
through the provision of educational plans to help physical and spiritual growth and development so that children have readiness to enter further education [21]. Early age provides a golden opportunity for children to learn, so it is called the golden age. At this age, children have extraordinary learning abilities [22].

Early childhood is a golden period for nation building by optimizing the growth and development of children. All children are intelligent. Children who get the right coaching at an early age will be able to improve their physical and mental health and well-being, which has an impact on increasing children's learning achievement, children's work ethic, and productivity so that they can be independent and optimize their potential [23]. Every child is born with more than one talent. For this reason, children need to be given education by enriching the learning environment, giving children or a place to express, be creative, and explore the potential that exists in their eyes

\subsection{Methods}

This research was conducted in Sidomulyo Belitang
State Kindergarten, Ogan Komering Ulu Timur. Test subject 60 Kindergarten children, 30 of whice of the experimental group, and the other the control group. This study uses a quantitative approach with the design used in this research is the pretest-posttest control group design [24].

The instrument used for pre-test and post-test data collection is a physical fitness instrument designed specifically for children aged 3 to 7 years, namely a physical fitness test with PREFIT [23]. The PREFIT Battery Test is the result of a systematic review based on existing field test evidence for the assessment of physical fitness in preschool children.

This PREFIT Battery Test includes Body Mass Index (BMI) weight and height, waist circumference, grip strength, standing long jump, $4 \times 10 \mathrm{~m}$ shuttle run, one leg stand and $20 \mathrm{~m}$ shuttle run test. All of these measurements are highly related to the current and future health status of children and adolescents [23]. The time required to administer this battery to a group of 20 people by four evaluators was approximately 2 hours 30 minutes. Here is the PREFIT Battery Test score sheet.

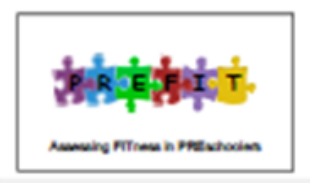

\section{PREFIT Battery: Assessing FITness in PREschool Children}

\section{Measurements}

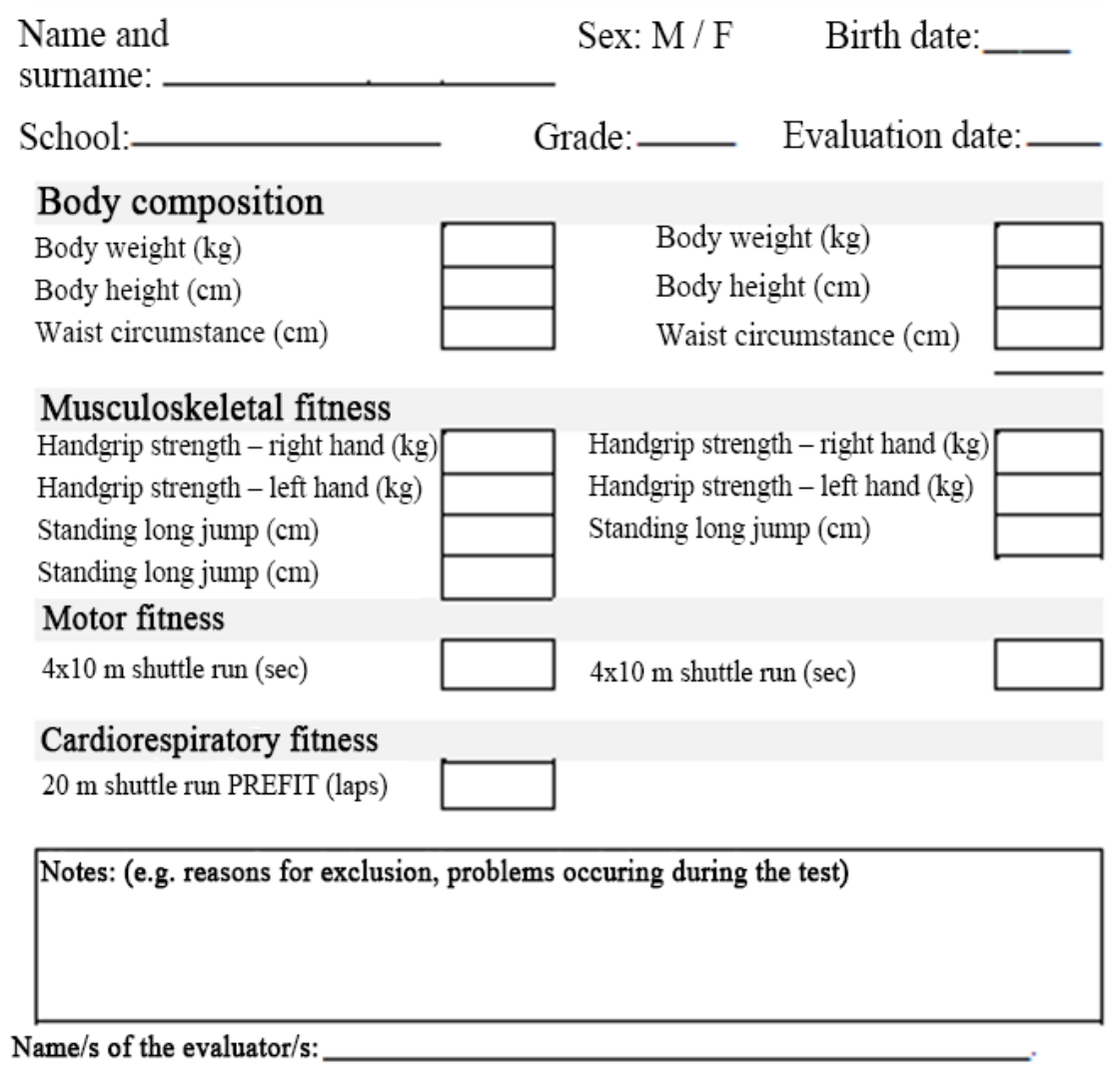

Figure 1. PREFIT Battery Test Assessment Sheet [23] 
Table 1. Graphic Representation of The Prefit Fitness Battery Tests [25]

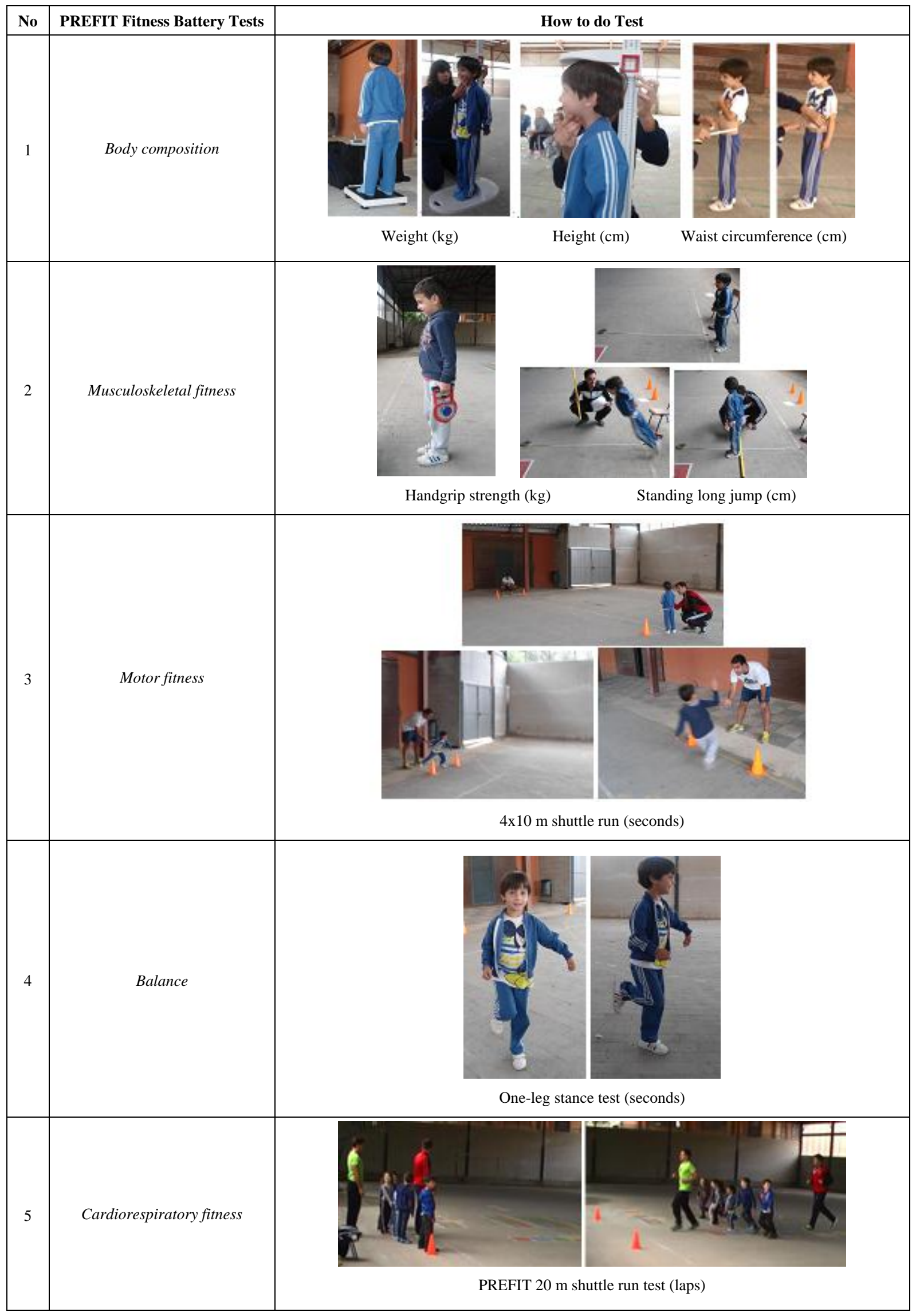


Table 2. Data on Pre-Fit Physical Fitness Pretest Results for Experimental Group ( $\mathrm{n}=30)$ and Control Group (n=30)

\begin{tabular}{|c|c|c|c|c|c|}
\hline \multirow{2}{*}{\multicolumn{2}{|c|}{$\begin{array}{c}\text { Group } \\
\text { Test Items }\end{array}$}} & \multicolumn{2}{|c|}{ Experiment } & \multicolumn{2}{|c|}{ Control } \\
\hline & & Average & SD & Average & SD \\
\hline \multicolumn{2}{|c|}{ Age (Years) } & 6.25 & 0.09 & 6.30 & 0.00 \\
\hline \multirow{3}{*}{ Body Composition } & Height $(\mathrm{cm})$ & 118.90 & 5.29 & 117.77 & 6.80 \\
\hline & Weight (kg) & 22.60 & 3.75 & 22.36 & 4.57 \\
\hline & Waist size $(\mathrm{cm})$ & 58.20 & 2.24 & 58.85 & 1.55 \\
\hline \multirow{2}{*}{ Musculoskeletal fitness } & HandGrip $(\mathrm{kg})$ & 6.58 & 1.02 & 6.56 & 0.96 \\
\hline & Standing Long Jump (cm) & 99.87 & 11.45 & 92.73 & 17.36 \\
\hline Motor Fitness & $4 x 10 m$ shuttle run $(s)$ & 13.44 & 2.14 & 13.84 & 2.14 \\
\hline Balance & One leg Stand Balance (s) & 17.74 & 1.52 & 19.43 & 1.39 \\
\hline Cardio respiratory & $20 m$ Shuttle run (laps) & 22.35 & 2.99 & 22.89 & 3.38 \\
\hline \multicolumn{2}{|c|}{$\begin{array}{l}\text { Final Score } \\
\end{array}$} & 196.54 & & 191.613 & \\
\hline
\end{tabular}

Table 3. Data on the results of the PREFIT physical fitness posttest in the Experiment Group ( $n=30)$ and the Control Group ( $=30$ )

\begin{tabular}{|c|c|c|c|c|c|}
\hline \multirow{2}{*}{\multicolumn{2}{|c|}{$\begin{array}{c}\text { Group } \\
\text { Test Items }\end{array}$}} & \multicolumn{2}{|c|}{ Experiment } & \multicolumn{2}{|c|}{ Control } \\
\hline & & Average & SD & Average & SD \\
\hline \multicolumn{2}{|c|}{ Age (Years) } & 6.25 & 0.09 & 6.30 & 0.00 \\
\hline \multirow{3}{*}{ Body Composition } & Height $(\mathrm{cm})$ & 118.90 & 5.29 & 117.77 & 6.80 \\
\hline & Weight (kg) & 22.60 & 3.75 & 22.36 & 4.57 \\
\hline & Waist size $(\mathrm{cm})$ & 58.20 & 2.24 & 58.85 & 1.55 \\
\hline \multirow{2}{*}{ Musculoskeletal fitness } & HandGrip $(\mathrm{kg})$ & 7.94 & 0.69 & 7.17 & 0.68 \\
\hline & Standing Long Jump (cm) & 103.20 & 15.78 & 97.73 & 17.36 \\
\hline Motor Fitness & $4 x 10 m$ shuttle run $(s)$ & 16.88 & 2.04 & 15.74 & 2.14 \\
\hline Balance & One leg Stand Balance $(s)$ & 24.93 & 1.39 & 20.53 & 1.39 \\
\hline Cardio respiratory & $20 m$ Shuttle run (laps) & 25.48 & 3.21 & 23.24 & 3.38 \\
\hline \multicolumn{2}{|c|}{$\begin{array}{l}\text { Final Score Average } \\
\end{array}$} & 211.55 & & 198.67 & \\
\hline
\end{tabular}

\section{Results and Discussion}

Test of fitness of preschool children is tested using PREFIT battery-Overall PREFIT battery is feasible and reliable for assessing physical fitness in preschool children [26, 27]. The results obtained from the application of Cheerful and Creative Children's gymnastics through several stages of assessment to test the effectiveness of the application of Cheerful and Creative Children's gymnastics to improve the physical fitness of kindergarten children.

From the data on the results of the early childhood physical fitness test for 60 children aged 5-6 years, a normality test of the data was carried out with the following results:

Table 4. Tests of Normality

\begin{tabular}{|c|c|c|c|c|c|c|}
\hline & \multicolumn{3}{|c|}{ Kolmogorov-Smirnov } & \multicolumn{3}{c|}{ Shapiro-Wilk } \\
\hline & statistic & df & Sig. & statistic & df & Sig. \\
\hline $\begin{array}{c}\text { Pretest } \\
\text { Kontrol }\end{array}$ & .139 & 30 & .145 & .945 & 30 & .125 \\
\hline $\begin{array}{c}\text { Pretest } \\
\text { Eksperimen }\end{array}$ & .121 & 30 & .200 & .914 & 30 & .119 \\
\hline $\begin{array}{c}\text { Posttest } \\
\text { Kontrol }\end{array}$ & .152 & 30 & .076 & .943 & 30 & .108 \\
\hline $\begin{array}{c}\text { Posttest } \\
\text { Eksperimen }\end{array}$ & .167 & 30 & .052 & .944 & 30 & .114 \\
\hline
\end{tabular}

*. This is a lower bound of the true significance

a. Lilliefors Significance Correction
Because this normality test consistan of me than 50 subjects, so the decision-making for this normality test uses the Test of Normality column in the Sig column. Kolmogorov-Smirnov, based on the table column Sig. Kolmogorov-Smirnov which is known that the significance value for the pre-test data for the control group is $0.145>0.05$, the experimental pre-test is $0.20>$ 0.05 , the post-test control group is $0.076>0.05$, the post-test experiment is $0,0520>0.05$. Because the significance for the entire study group is greater than (0.05), it can be said that the research data are normally distributed.

Table 5. Test of Homogeneity of Variances

\begin{tabular}{|c|c|c|c|}
\hline \multicolumn{4}{|c|}{ Post-test Final Score } \\
\hline Levene Statistic & df1 & df2 & Sig. \\
\hline .009 & 1 & 58 & .923 \\
\hline
\end{tabular}

Based on the table of test of homogeneity of variance above, it is known that the significance value for the final value data (post-test) for the control group and the experimental group is $0.923>0.05$.It can be said that the research data is homogeneous.

Because the data collected already met the prerequisite test criteria, then an independent sample t-test was then conducted to determine whether there was a difference in average between experimental group and control group who were given the Cheerful and Creative Child exercise model. 
Table 6. Independent Samples Test

\begin{tabular}{|c|c|c|c|c|c|c|c|c|c|c|}
\hline & \multicolumn{2}{|c|}{\begin{tabular}{|c|} 
Levene's Test \\
for Equality of \\
Variances
\end{tabular}} & \multicolumn{7}{|c|}{ t-test for Equality of Means } \\
\hline & & \multirow[t]{2}{*}{$\mathbf{F}$} & \multirow[t]{2}{*}{ Sig. } & \multirow[t]{2}{*}{$\mathbf{t}$} & \multirow[t]{2}{*}{ df } & \multirow{2}{*}{$\begin{array}{c}\text { Sig. } \\
\text { (2-tailed) }\end{array}$} & \multirow{2}{*}{$\begin{array}{c}\text { Mean } \\
\text { Difference }\end{array}$} & \multirow{2}{*}{$\begin{array}{l}\text { Std. Error } \\
\text { Difference }\end{array}$} & \multicolumn{2}{|c|}{$\begin{array}{c}\text { 95\% Confidence Interval } \\
\text { of the Difference }\end{array}$} \\
\hline & & & & & & & & & Lower & Upper \\
\hline \multirow{2}{*}{$\begin{array}{c}\text { Posttest Final } \\
\text { Score }\end{array}$} & \begin{tabular}{|c|} 
Equal variances \\
assumed
\end{tabular} & .009 & .923 & 1.351 & 58 & .028 & 12.88133 & 9.53594 & -6.20693 & 31.96960 \\
\hline & $\begin{array}{c}\text { Equal variances } \\
\text { not assumed }\end{array}$ & & & 1.351 & 57.218 & .028 & 12.88133 & 9.53594 & -6.21249 & 31.97516 \\
\hline
\end{tabular}

Table 7. Calculation Results of N-gain Score Test

\begin{tabular}{|c|c|c|c|c|}
\hline \multirow{2}{*}{ No } & \multicolumn{2}{|c|}{ Experiment Class } & \multicolumn{2}{|c|}{ Control Class } \\
\hline & N-Gain Score (\%) & Category & N-Gain Score (\%) & Category \\
\hline 1 & 75 & Effective Enough & 41,7 & Less Effective \\
\hline 2 & 86 & Effective & 53,8 & Less Effective \\
\hline 3 & 61,5 & Effective Enough & 36,2 & Ineffective \\
\hline 4 & 82,2 & Effective & 22,2 & Ineffective \\
\hline 5 & 62,5 & cukup efektif & 60 & Effective Enough \\
\hline 6 & 100 & Effective & 35,6 & Ineffective \\
\hline 7 & 61,1 & Effective Enough & 20.5 & Ineffective \\
\hline 8 & 83,3 & Effective & 40 & Less Effective \\
\hline 9 & 85 & Effective & 40 & Less Effective \\
\hline 10 & 48,3 & Less Effective & 90 & Effective \\
\hline 11 & 83,3 & Effective & 66,7 & Effective Enough \\
\hline 12 & 57,1 & Effective Enough & 80 & Effective \\
\hline 13 & 77,8 & Effective & 50 & Less Effective \\
\hline 14 & 68,2 & Effective Enough & 37,9 & Ineffective \\
\hline 15 & 60 & Effective Enough & 71,4 & Effective Enough \\
\hline 16 & 93,8 & Effective & 72,7 & Effective Enough \\
\hline 17 & 66,7 & Effective Enough & 51 & Less Effective \\
\hline 18 & 94,7 & Effective & 28,6 & Ineffective \\
\hline 19 & 87,5 & Effective & 66,7 & Effective Enough \\
\hline 20 & 95,2 & Effective & 33,3 & Ineffective \\
\hline 21 & 81,3 & Effective & 50 & Less Effective \\
\hline 22 & 94,7 & Effective & 30,7 & Ineffective \\
\hline 23 & 80 & Effective & 44,4 & Less Effective \\
\hline 24 & 71,4 & Effective Enough & 100 & Effective \\
\hline 25 & 76,5 & Effective & 33,3 & Ineffective \\
\hline 26 & 76,5 & Effective & 81,8 & Effective \\
\hline 27 & 75 & Effective Enough & 45,5 & Less Effective \\
\hline 28 & 85 & Effective & 41,7 & Less Effective \\
\hline 29 & 80,6 & Effective & 56.3 & Effective Enough \\
\hline 30 & 75 & Effective Enough & 76,9 & Effective \\
\hline Average & 77,51 & Effective & 52,93 & Less Effective \\
\hline $\begin{array}{l}\text { Minimum } \\
\text { Value }\end{array}$ & 48,30 & & 22,20 & \\
\hline $\begin{array}{c}\text { Maximum } \\
\text { Value }\end{array}$ & 100 & & 100 & \\
\hline
\end{tabular}

Based on the table 6 , the value of $t=1.351$ and the value of Sig. (2-tailed) or p-value $=0.028<0.05$ then Ho (Statistical Hypothesis) is rejected and Ha (Alternative Hypothesis) is accepted, meaning that there is a significant increase in the physical fitness results of Kindergarten children after being given the Cheerful and Creative Child gymnastics model. Furthermore, to determine the effectiveness of the application of the Cheerful and Creative Children's exercise model, it can be tested by calculating the N-Gain Score. The gain score is the difference between the post-test and pre-test scores. The $\mathrm{N}$-gain score test is carried out by calculating the difference between a certain pre-test (test before the application of the method/treatment) and the post-test (test 
after applying a certain method/treatment) [28].

Based on the table above, the average N-gain score for the experimental class is $77.51 \%$ with the "Effective" category, with a minimum N-gain score of $48.30 \%$ and a maximum $\mathrm{N}$-gain score of $100 \%$. Meanwhile, the average $\mathrm{N}$-gain score for the control class is $52.93 \%$ in the "Less Effective" category with a minimum $\mathrm{N}$-gain score of $22.20 \%$ and a maximum $\mathrm{N}$-gain score of $100 \%$. Thus, the use of the "Effective" Cheerful and Creative Children's exercise model can improve the physical fitness of kindergarten children

Physical fitness possessed inearly childhood can help them in carrying out their learning and playing activities. Physical fitness has an important meaning for children, among others, it can improve the function of body organs, social-emotional, sportsmanship, and the spirit of competition. According to Simon in [29], by having high physical fitness, children can carry out daily activities for a longer time than children who have low physical fitness.

The important role of physical fitness for children is to make children physically, mentally, and emotionally ready, psychologically and physically mature, and to lead children to be enthusiastic about learning and practicing so that the expected learning achievements will be achieved [30]. Early childhood who is active in sports activities will have a better quality of life than children who are not active. Resistance to disease, resistance to fatigue, rate of growth and development, even intellectual level will be better than children who are inactive [31].

The opinion of Physical activity in childhood is closely associated with health. Physical activity refers to all movements of the body caused by the contraction of the skeletal muscles [32] and plays a vital role in energy consumption [33]. Therefore, physical activity or sports should always be given to early childhood.

\section{Conclusion}

Based on the results of the study, it can be concluded that the Cheerful and Creative Child gymnastics model in gymnastics learning for kindergarten children consists of a series of rhythmic gymnastics movements and the theme of myself, the theme of transportation, the theme of the profession, the theme of animals, and the theme of the surrounding nature can improve physical fitness in kindergarten children.

Suggestions for utilization based on the results of the research on the application of this Cheerful and Creative Child exercise model is that the exercise learning model applied be used by Early Childhood Education Programs teachers as a reference in early childhood movement learning, especially in kindergarten children to make it funier, and can improve children's physical fitness. To realize this, it is necessary to increase the preparation of motion before teaching, the willingness and creativity of the teacher to always improve the quality of learning with various forms of fun movement learning variations so that it can stimulate children's growth and development.

\section{Acknowledgements}

The authors would like to thank AT-TAQWA IT Kindergarten and IT Qurrata Ayun Kindergarten in Belitang sub-district who have supported researchers in conducting research.

\section{REFERENCES}

[1] Rahman, H. S. (2005). Konsep Dasar Pendidikan Anak Usia Dini / Hibana S Rahman. PGTKI Press.

[2] Prastiwi, B. K. \& Suharjana. (2014). Constructing A Test And Standard Of Physical Fitness For 4-6 Years Old Children In Diy. Jurnal Keolahragaan, 2(1).

[3] Overy, K. \& Szakacs, I. M. (2006). Being Together in Time: Musical Experience and the Mirror Neuron System. University of California Press, 26(5), 489-504. https://doi.org/10.1525/mp.2009.26.5.489

[4] Kadir, A. (2010). Misteri otak kiri manusia. Diva Press.

[5] Galih Dwi Pradipta. (2017). Strategi Peningkatan Keterampilan Gerak Untuk Anak Usia Dini Taman Kanak-Kanak B. Jendela Olahraga, Vol 2(No 1), h. 143.

[6] Sujiono, B. (2008). Metode Pengembangan Fisik. Universitas Terbuka.

[7] Yumaika, C., \& Ardisal. (2020). Efektivitas Senam Ceria Untuk Meningkatkan Kemampuan Motorik Kasar Anak Tunagrahita Ringan. Journal of Multidicsiplinary Research and Development, 2(3), 46-52.

[8] Caine, D. J., Russell, K., \& Lim, L. (2013). Handbook of Sport Medicine and Science Gymnastics. Wley-Blackwell A John Wiley \& Sons, Ltd.

[9] Mehrtash, M., Rohani, H., Farzaneh, E., \& Nasiri, R. (2015). The effects of 6 months specific aerobic gymnastic training on motor abilities in $10-12$ years old boys. Science of Gymnastics Journal, 7(1), 51-60.

[10] Fahrezi, F. (2017). Pengembangan Model Pembelajaran Senam Healty Fun untuk Anak SLB di Kota Magelang". Journal of Physical Education, Sport, Health and Recreations, 6(1), 18.

[11] Polat, S. Ç. (2018). The Effect of Technical Competence in Balance Elements of Rhythmic Gymnastics on the Sportive Success of Taekwondo Poomsae Athletes. Journal of Education and Training Studies, 6(9), 2017-2020. https://doi.org/10.11114/jets.v6i9.3375

[12] Sutisna. (2014). Pendidikan Jasmani media olahraga dan berprestasi. yudhistira.

[13] Caine, D. J., Russell, K., \& Lim, L. (2013). Handbook of Sport Medicine and Science Gymnastics. Wley-Blackwell A John Wiley \& Sons, Ltd. 
[14] Mehrtash, M., Rohani, H., Farzaneh, E., \& Nasiri, R. (2015). The effects of 6 months specific aerobic gymnastic training on motor abilities in $10-12$ years old boys. Science of Gymnastics Journal, 7(1), 51-60.

[15] Ismaryati. (2008). Peningkatan Kelincahan Atlet Melalui Penggunaan Metode Kombinasi Latihan Sirkuit-Pliometrik Dan Berat Badan (11th ed.).

[16] Ortega, F. B., Ruiz, J. R., Castillo, M. J., \& Sjöström, M. (2008). Physical fitness in childhood and adolescence: A powerful marker of health. In International Journal of Obesity. https://doi.org/10.1038/sj.ijo.0803774

[17] Sukadiyanto, dan Muluk, D. (2011). Pengantar Teori dan Metodologi Melatih Fisik. Lubuk Agung.

[18] Nurhasan. (2013). Tes dan Pengukuran Pendidikan Olahraga. FPOK UPI.

[19] Pinho, C. S., Caria, A. C. I., Júnior, R. A., \& Pitanga, F. J. G. (2020). The effects of the COVID-19 pandemic on levels of physical fitness. Revista Da Associacao Medica Brasileira. https://doi.org/10.1590/1806-9282.66.S2.34

[20] Sasongko, N. D. (2017). Pengembangan Multimedia Pembelajaran Menggunakan Aodbe Flash Mengenal Konsep dan Lambang Bilangan PAUD. Jurnal PG-PAUD Trunujoyo, 4(2)

[21] Sugiyono. (2015). Metode Peneliltian Pendidikan Pendekatan Kuantitatif, Kualitatif, dan R\&D. Alfabeta.

[22] Permendikbud No 137. (2014). Standar Nasional Pendidikan Anak Usia Dini.

[23] Granada, U. de. (2011). PREFIT Battery: Assessing FITness in PREschoolers.

[24] Mursid. (2015). Belajar dan Pembelajaran PAUD. PT. Remaja Rosdakarya.

[25] Cadenas-Sanchez, C., Martinez-Tellez, B., Sanchez-Delgado, G., Mora-Gonzalez, J., Castro-Piñero, J., Löf, M., Ruiz, J. R., \& Ortega, F. B. (2016). Assessing physical fitness in preschool children: Feasibility, reliability and practical recommendations for the PREFIT battery. Journal of Science and Medicine in Sport, 19(11), 910-915. https://doi.org/10.1016/j.jsams.2016.02.003

[26] Ortega, Francisco B., Cadenas-Sánchez, C., Sánchez-Delgado, G., Mora-González, J., Martínez-Téllez, B., Artero, E. G., Castro-Piñero, J., Labayen, I., Chillón, P., Löf, M., \& Ruiz, J. R. (2015). Systematic Review and Proposal of a Field-Based Physical Fitness-Test Battery in Preschool Children: The PREFIT Battery. Sports Medicine, 45(4), 533-555. https://doi.org/10.1007/s40279-014-0281-

[27] Raharjo, S. (2019). Cara Menghitung N-Gain Score Kelas Eksperimen dan Kontrol dengan SPSS. SPSS Indonesia. https://www.spssindonesia.com/2019/04/cara-menghitungn-gain-score-spss.html

[28] Gustiana. (2011). Pengaruh Permainan modifikasi terhadap Kemampuan Motorik Kasar dan Koqnitif Anak Usia Dini. Jurnal Pendidikan, Edisi Khus(2), 191-200.

[29] Wirnantika, I., Pratama, B. A., \& Hanief, Y. N. (2017). Survey Tingkat Kebugaran Jasmani Siswa Kelas IV SDN Puhrubuh I dan MI Mambaul Hikam di Kabupaten Kediri Tahun Ajaran 2016/2017. Jurnal SPORTIF: Jurnal Penelitian Pembelajaran, 3(2), 240. https://doi.org/10.2940 7/js_unpgri.v3i2.11898

[30] Paiman. (2009). Olahraga dan Kebugaran Jasmani (Physical Fitness PadaAnak Usia Dini. Jurnal Cakrawala Pendidikan, 3. https://doi.org/10.21831/cp.v3i3.304

[31] WHO. (2015). World Health Statistic Report 2015. World Health Organization.

[32] Park, Y., \& Moon, J. (2018). Effects of Early Morning Physical Activity on Elementary School Students' Physical Fitness and Sociality. IEJEE: International Electronic Journal of Elementary Education, 10(4), 441-447.

[33] Ihsana El-Khuluqo. (2015). Manajemen PAUD (Pendidikan Anak Usia Dini): Pendidikan Taman Kehidupan Anak. PT. Pustaka Pelajar. 